\title{
Non-selective grazing impacts on soil-properties of the Nama Karoo
}

\author{
PETRUS C. BEUKES AND RICHARD M. COWLING
}

Authors are Senior Lecturer, Department of Nature Conservation and Oceanography, Cape Technikon, P.O. Box 652, Cape Town 8000, South Africa; and research professor, Terrestrial Ecological Research Unit, Department of Botany, University of Port Elizabeth, P.O. Box 1600, Port Elizabeth 6001, South Africa.

\begin{abstract}
Non-selective grazing (NSG) is a relatively novel way of farming livestock in the Nama Karoo of South Africa. Our key question was how heavy grazing under this high-intensity, low-frequency grazing system would impact on certain soil properties. The study was designed to compare the impacts of NSG (treatment) with no grazing (control) in terms of: (1) amount of soil organic carbon (OC); (2) soil microbial respiration rates; (3) soil stability and infiltration properties. The treatment significantly lowered the amount of $\mathrm{OC}$ in the topsoil. Microbial respiration rates corresponded with the fertile patch matrix in both treatment and control with significantly higher respiration rates measured under plants compared to open, unvegetated areas. Respiration rates in treatment open areas were significantly higher than in control open areas. There was a trend $(P<0.1)$ for higher aggregate stability, final infiltration rate and cumulative infiltration for treatment open soils compared to controls during an initial rain event of $44 \mathrm{~mm} \mathrm{hour}^{-1}$ in a rainfall simulator. During a second rain event on sealed soils only aggregate stability was significantly higher for treatment compared to control soils. We conclude that the short-duration, low-frequency, intensive herbivory by livestock under the non-selective grazing system resulted in a more active microbial community, which turned over organic matter more rapidly and led to higher soil stability and infiltration capacity of open, unvegetated soils. We present this as an example of conditions where herding by high densities of large herbivores can have positive impacts on soil quality.
\end{abstract}

Key Words: grazing system, hoof action, infiltration, intensive herbivory, microbial respiration, semi-arid

Grazing animals primarily affect rangeland soils by direct impacts through trampling and dunging (Smoliak et al. 1972), and indirectly by altering plant community structure (Thurow et al. 1988, Dormaar et al. 1997). Soil quality, or productive potential, as characterized by, amongst others, infiltration rate, nutrient status, and stability (resistance to erosion), determines the flows of nutrients and water between soils and plants (Tongway and Hindley 1995). Management may change these soil qualities, either by ensuring resource conservation (soil, nutrients, water) within the system, or by degrading the system so that resources

At the time of the research, the co-author was Director, Institute for Plant Conservation, Botany Department, University of Cape Town, Private Bag, Rondebosch 7701, South Africa.

Manuscript accepted 9 Nov. 02.

\section{Resumen}

El apacentamiento no selectivo (NSG) es una forma relativamente nueva de manejar el ganado en el Nama Karoo de Sudáfrica. Nuestra pregunta clave fue como el apacentamiento fuerte bajo este sistema de apacentamiento de alta intensidad baja frecuencia impactaría en las propiedades del suelo. El estudio se diseño para comparar los impactos del NSG (tratamiento) con el no apacentamiento (control) en términos de: (1) cantidad de carbón orgánico en el suelo (OC); (2) tasas de respiración microbiana en el suelo y (3) propiedades de infiltración y estabilidad del suelo. El tratamiento disminuyo significativamente la cantidad de $O C$ en la capa superior del suelo. Tanto en el tratamiento como en el control las tasas de respiración microbiana correspondieron a las de una matriz de parches fértiles y el control con tasas de respiración significativamente mayores bajo las plantas que en los espacios abiertos sin vegetación. Las tasas de respiración en las áreas abiertas del tratamiento fueron significativamente mayores que las tasas de las áreas abiertas del control. Hubo una tendencia $(P<0.1)$ de mayor estabilidad de los agregados, mayor tasa de infiltración final e infiltración acumulada en los suelos abiertos del tratamiento comparados con el control, esto durante un evento inicial de lluvia de $44 \mathrm{~mm}$ hora $^{-1}$ realizado con en el simulador de lluvia. Durante un segundo evento de lluvia sobre el suelo sellado solo la estabilidad de los agregados fue significativamente mayor en el tratamiento que en los suelos del control. Concluimos que la corta duración, baja frecuencia y herbívora intensa del ganado bajo el sistema de apacentamiento no selectivo resulta en una comunidad microbiana más activa, la cual actuó más rápidamente sobre la materia orgánica lo que conduce a una mayor estabilidad del suelo y mayor capacidad de infiltración de los suelos abiertos sin vegetación. Presentamos esto como un ejemplo de las condiciones donde el apacentamiento con altas densidades de grandes herbívoros puede impactar positivamente en la calidad del suelo.

are lost or "leaked" (Tongway and Hindley 1995). Biologically mediated soil processes such as decomposition, mineralization, production and maintenance of macropores, production of soil aggregates, and fixation, are critical for the maintenance and restoration of soil production potential (Whitford and Herrick 1996). Grazing animals are the "tools" by which the rangeland manager can either maintain or reduce productive potential, depending mainly on stocking rate and grazing systems applied. The correct use of these tools can have long-term economic implications for the livestock operation (Savory 1983, Biondini et al. 1998, Beukes et al. 2002). 
There is an extensive literature on the merits of different stocking rates and grazing systems. Some reviews (e.g. O'Reagain and Turner 1992) suggest that there is little evidence to support rotational grazing in favour of continuous grazing. Others have postulated that grazing systems that combine short periods of high grazing intensity with prolonged periods of rest (high-intensity-low-frequency grazing $\approx$ non-selective grazing) simulates the herding of wild ungulates and may play an important role in influencing range condition (Acocks 1966). McNaughton et al. (1988) have shown that removal of this type of grazing in the Serengeti grasslands leads to an increase in $\mathrm{N}$ immobilized in litter and standing dead biomass, and a reduction in soil microbial turnover rates and net soil $\mathrm{N}$ mineralization. This stimulated McNaughton's (1993) grazing optimization theory-grazing stimulates soil and plant processes which, in turn, maximize primary production through plant compensatory growth mechanisms. However, this theory is still being intensively debated (Painter and Belsky 1993, Biondini et al. 1998).

A number of studies have shown that heavy grazing leads to plant compositional changes, a reduction in total organic cover, and changed physical and chemical properties of the topsoil layers with a resultant reduction in infiltration rates (Smoliak et al. 1972, McCalla et al. 1984, Graetz and Tongway 1986, Thurow et al. 1986, Biondini and Manske 1996, Mworia et al. 1997, Biondini et al. 1998). The literature, however, is replete with contradictory results on the effects of grazing on soils, possibly a consequence of the different environments, soils and grazing management systems of the trials (Lavado et al. 1996). One of the reasons for these contradictions is the varied interpretations of "heavy grazing". Although heavy grazing is generally understood to mean that grazing animals are kept in an area (paddock) until they have removed up to $90 \%$ of the aboveground biomass (Biondini et al. 1998), this can be achieved by either keeping relatively few animals for a long time in the paddock (which translates into short rest periods) or by stocking high densities for a short time in numerous small paddocks (which translates into longer rests depending on the number of paddocks available). We argue that these differences are important and will result in different impacts on soils and vegetation. We postulate that heavy grazing under a high-intensity-low-frequency/non-selective grazing system would improve soil quality through its concentrated but short duration impacts on ecosystem processes (McNaughton et al. 1988, Savory 1991).

This study was designed to test this hypothesis by comparing the impacts of non-selective grazing (treatment) vs. no grazing (control) on certain soil quality indicators viz: (1) total soil organic carbon (OC); (2) soil microbial respiration rates; (3) aggregate stability, infiltration rate, erodibility, and cumulative infiltration. In each case we predicted that the grazing treatment would increase OC, microbial respiration rates, and soil stability and infiltration.

\section{Materials and Methods}

\section{Study Area}

Fieldwork was conducted on the farm Elandsfontein (7,000 ha) situated $32 \mathrm{~km}$ north-east of Beaufort West in the Nama Karoo $\left(32^{\circ} 15^{\prime} \mathrm{S} / 22^{\circ} 45^{\prime} \mathrm{E}\right)$. A series of doloritic rocky outcrops run across the farm with the rest of the landscape consisting of level to near-level pediments. Soils are of mixed origin, derived from dolerite weathering products and Karoo System shales or shale-derived pedisediments (Ellis and Lambrechts 1986). The reddish coloured duplex soils have a coarse sandy loam texture, are relatively rich in most plant nutrients (topsoil plant-available $\mathrm{P}>$ $20 \mathrm{mg} / \mathrm{kg}$; topsoil exchangeable $\mathrm{K}>7 \%$ ), and have low levels of salts (electrical resistance $>1,000 \mathrm{ohms}$ ), exchangeable $\mathrm{Na}(\mathrm{ESP}<1 \%)$, and organic carbon $(\mathrm{OC}=$ $\pm 0.2 \%)$.

The mean annual rainfall for the farm for the period 1987-1998 was $212 \mathrm{~mm}$ year $^{-1}$ with a CV of $47 \%$. Severe droughts occur regularly in the Nama Karoo with the last one being the 1990-1994 drought when Elandsfontein recorded a mean of $139 \mathrm{~mm}$ year $^{-1}$. Fieldwork at Elandsfontein commenced in the drought-breaking year of $1995(238 \mathrm{~mm})$ after the very dry 1994 $(33 \mathrm{~mm})$. There is a trend for more rainfall, with a higher reliability, to fall during summer months. Frontal systems bring light rain in winter while summer rains are often characterized by brief cloudbursts resulting in rapid run-off. The mean annual A-pan equivalent potential evapotranspiration is $2,400-2,600 \mathrm{~mm}$ (Schulze 1997).

The vegetation is classified by Acocks (1975) as veld type 26, Karroid Broken Veld; and by Low and Rebelo (1996) as Central Lower Karoo. This semi-arid grassy shrubland is dominated by grasses, mainly species of Stipagrostis and
Eragrostis, while Pentzia incana (Thunb.) Kuntze and Rosenia humilis (Less.) Bremer are dominant dwarf shrubs. Rocky sites include a sparse, tall shrub to low tree stratum where the principle genus is Rhus. A highly variable ephemeral, and scarce succulent component exists.

Over a period of 30 years the landowner subdivided the farm into many small paddocks. Only since the early 1990's were these paddocks sufficiently small to achieve the high grazing intensities of the non-selective grazing system. Currently the infrastructure on Elandsfontein consists of 147 paddocks arranged in wagonwheel layouts around 38 permanent watering points. Large mixed herds of Nguni cattle, Merino sheep, and Boer goats (in an average ratio of $1: 14: 3$ ) are rotated through the paddocks in a non-selective grazing system. The number of herds is reduced as far as possible to concentrate animals and minimize the grazing period ( $<14$ days). Grazing intensities of $40-60$ Large Stock Unit Grazing Days per hectare (LSU*days/ha where $1 \mathrm{LSU}$ is the equivalent forage intake of a $455 \mathrm{~kg}$ steer) are applied (compared to 10- 20 of more conventional group camp systems), after which a paddock is rested for at least a full year. A rumen stimulant in the form of cut saltbush (Atriplex nummularia Lindl.) is supplied to improve animals' intake of poorer quality fibre towards the end of a period of occupation.

This non-selective grazing system differs from short-duration grazing (SDG) as summarized by Holechek et al. (2000) in that high grazing intensities are achieved by reducing numbers of herds and paddock sizes and not by increasing stocking rate. With substantially more paddocks non-selective grazing also allows for much longer periods of rest compared to shortduration grazing.

\section{Experimental design}

In April 1995, four paddocks (A, B, C and D) on Elandsfontein were subjectively assessed as similar in terms of topography, soils, and vegetation, and were identified as the 4 replicates for this study. Although the paddocks differed in size $(A=34$ ha, $\mathrm{B}=87, \mathrm{C}=108, \mathrm{D}=32$ ) the treatment, grazing intensity (measured as Large Stock Unit Grazing Days/ha = LSU*days/ha), were kept similar across the replicates by adjusting the grazing period (days). A 5 strand stock fence was used to erect a $50 \mathrm{~m} \times 50 \mathrm{~m}$ exclosure in each paddock. The exclosure fences were positioned away from watering points and stock paths, and excluded livestock graz- 
ing but not herbivory by indigenous vertebrates steenbok (Raphicerus campestris), hares (Lepus spp.), tortoises (Psammobates spp.), porcupine (Hystrix austroafricanae), and invertebrates. The fenced areas were regarded as controls whereas the adjacent $50 \mathrm{~m} \times 50 \mathrm{~m}$ areas were regarded as the grazing treatments.

\section{The Treatment}

After the exclosures were set up in April 1995, each paddock received a non-selective grazing (NSG) treatment each year thereafter (until 1998) by stocking a combination of Nguni cattle, Merino sheep, and Boer goats at grazing pressures varying from 40 to 60 LSU*days/ha. Grazing intensities varied between years because of food availability, and animal reproductive status and condition, but were always kept as similar as possible across replicates by adjusting the length of the grazing period (days). The treatment was not applied during any particular season, but the aim was always to herd as many animals together as was available, and to keep the grazing period within the maximum of about 2 weeks (it varied between 2 and 16 days). These high grazing intensities were achieved by herding up to 348 LSU in a 32 ha paddock for 5 days (1998 treatment). To extend the period of occupation by a few days, and thereby force the animals to ingest more fibrous, less palatable material, they were supplied with 1.5-2 tonnes of cut saltbush (Atriplex nummularia Lindl.) every alternate day. The woody portion $(>50 \%)$ of the saltbush shoots does not get utilized and remains on the land as litter. The leaf material with an average $22 \%$ protein, helps to maintain rumen function and improves intake of low quality fibre (Barnard 1986). Care was taken not to deposit the saltbush on or nearby the $50 \mathrm{~m}$ x $50 \mathrm{~m}$ treatment areas. For experimental purposes the treatment was applied annually, but under normal circumstances a paddock would receive a rest period of more than a year (147 paddocks at \pm 9 days per paddock converts into a theoretical rest period of 3-4 years).

\section{Soil organic carbon (OC)}

In June 1998, within a month after the treatment, 3 of the 4 replicate paddocks were selected for collecting soil samples for OC measurements. Owing to financial constraints, OC measurements were taken in only 3 (A, C and D) of the 4 experimental paddocks. One, $5 \mathrm{~m} \times 5 \mathrm{~m}$ plot was randomly positioned inside the control and treatment areas of each paddock. Care was taken to avoid stock paths. Each plot was subdivided into a grid with 100 cells each 100 soil samples (top $5 \mathrm{~cm}$ ) were systematically collected in each plot. After passing each soil sample through a $2 \mathrm{~mm}$ sieve to remove larger fractions, the OC content (\%) was determined using the Walkley and Black method (Nelson and Sommers 1982).

\section{Soil microbial respiration rates}

Every year since 1996, within a month after the treatment had been applied, soil samples were collected from control and treatment areas of the 4 replicate paddocks for measuring microbial respiration rates. Samples were randomly taken from the top $5 \mathrm{~cm}$ of open, unvegetated areas between shrub and grass clumps (intermound), as well as from mound soils underneath shrubs (mainly Pentzia incana (Thunb.) Kuntze). Samples were passed through a $2 \mathrm{~mm}$ sieve, moistened with 10 $\mathrm{g}$ water per $100 \mathrm{~g}$ air-dry soil, and stored in a polythene bag for 1 week. Bags were shaken every day to aerate the soil. After the incubation period of 1 week, $\mathrm{CO}_{2}$ release as a result of microbial respiration was determined using $\mathrm{NaOH}$ to react with the $\mathrm{CO}_{2}$ in respiration flasks. After approximately 1 week (the exact time was noted) in the respirometers, the free $\mathrm{NaOH}$ was titrated with $\mathrm{HCl}$. Titrations were standardized against a control respirometer with sand instead of soil. The water content of the moist soil at the time the respirometers were set up was determined by drying sub-samples overnight at $105^{\circ}$ C. Soil microbial respiration rates were expressed as $\mathrm{g} \mathrm{CO}_{2} \mathrm{~g}^{-1}$ air-dry soil second ${ }^{-1}$ (for more detail see Rowell (1994) pp. 117 $-119)$.

\section{Aggregate stability, infiltration rate, erodibility, and cumulative infiltration} Soil sample collection and preparation

In June 1998, within a month after the grazing treatment, $20 \mathrm{~kg}$ soil samples were collected from the top $10 \mathrm{~cm}$ of open, unvegetated areas in treatment and control areas of all 4 paddocks. The collected measuring $0.5 \mathrm{~m} \times 0.5 \mathrm{~m}$. Using this grid,

samples were air-dried and crushed to pass a $4 \mathrm{~mm}$ sieve.

\section{Rainfall simulation}

Infiltration, runoff and interrill erosion were measured by using a rainfall simulator with a rotating disk, such as those developed by Morin et al. (1967). Three replicates of a soil were packed $20 \mathrm{~mm}$ deep in $300 \mathrm{~mm} \times 500 \mathrm{~mm}$ boxes, over an $80 \mathrm{~mm}$ deep layer of coarse sand. The boxes were placed in the rainfall simulator at a slope of $5 \%$. The soil was first saturated from the bottom with tap water and then exposed to simulated rainfall of distilled water with an electrical conductivity value of $1.0 \mathrm{mS} \mathrm{m}^{-1}$. The mechanical parameters of the applied rain were: instantaneous application rate of $44 \mathrm{~mm}_{\text {hour }}^{-1}$; water drop average diameter of $19 \mathrm{~mm}$; median drop velocity of the rain event, $6.02 \mathrm{~m} \mathrm{~second}^{-1}$; and the kinetic energy was $18.1 \mathrm{~J} \mathrm{~mm}^{-1} \mathrm{~m}^{-2}$. The volumes of water percolating through the soil were recorded at 2-minute intervals during an event of 2 hours. Timed runoff samples were collected at 2-minute intervals during the 2-hour event, weighed, oven dried at $105^{\circ} \mathrm{C}$, and reweighed to determine runoff rate, sediment concentration, and sediment yield. During the first storm seal formation occurred (a thin wet layer of low hydraulic conductivity that forms at the soil surface during a storm) as a result of physical and chemical processes initiated by the multiple impacts of the raindrops (Levy 1988).

After the first storm, the trays with soil were removed from the rain simulator and dried at room temperature to form a crust (hard setting of seal with drying). The dried soil was then again subjected to a second storm similar as the first storm where similar soil parameters were measured.

\section{Calculations}

Cumulative infiltration and final infiltration rate

In many arid and semi-arid region soils, the amount of water that infiltrates the soil is determined by the hydraulic conductivity of a seal at the soil surface (Ben-Hur et

Table 1. Summary statistics for soil organic carbon (\%) measurements from 3 paddocks (A, C, and D) at Elandsfontein in June 1998.

\begin{tabular}{|c|c|c|c|c|c|c|}
\hline \multirow[b]{3}{*}{ Statistic } & \multirow{2}{*}{\multicolumn{2}{|c|}{ A }} & \multicolumn{2}{|c|}{ Paddock } & \multirow{2}{*}{\multicolumn{2}{|c|}{$\mathrm{D}$}} \\
\hline & & & $\mathrm{C}$ & & & \\
\hline & Treatment & Control & Treatment & Control & Treatment & Control \\
\hline Mean $(n=100)$ & 0.26 & 0.31 & 0.42 & 0.43 & 0.58 & 0.63 \\
\hline Standard Deviation & 0.13 & 0.12 & 0.11 & 0.11 & 0.24 & 0.25 \\
\hline
\end{tabular}



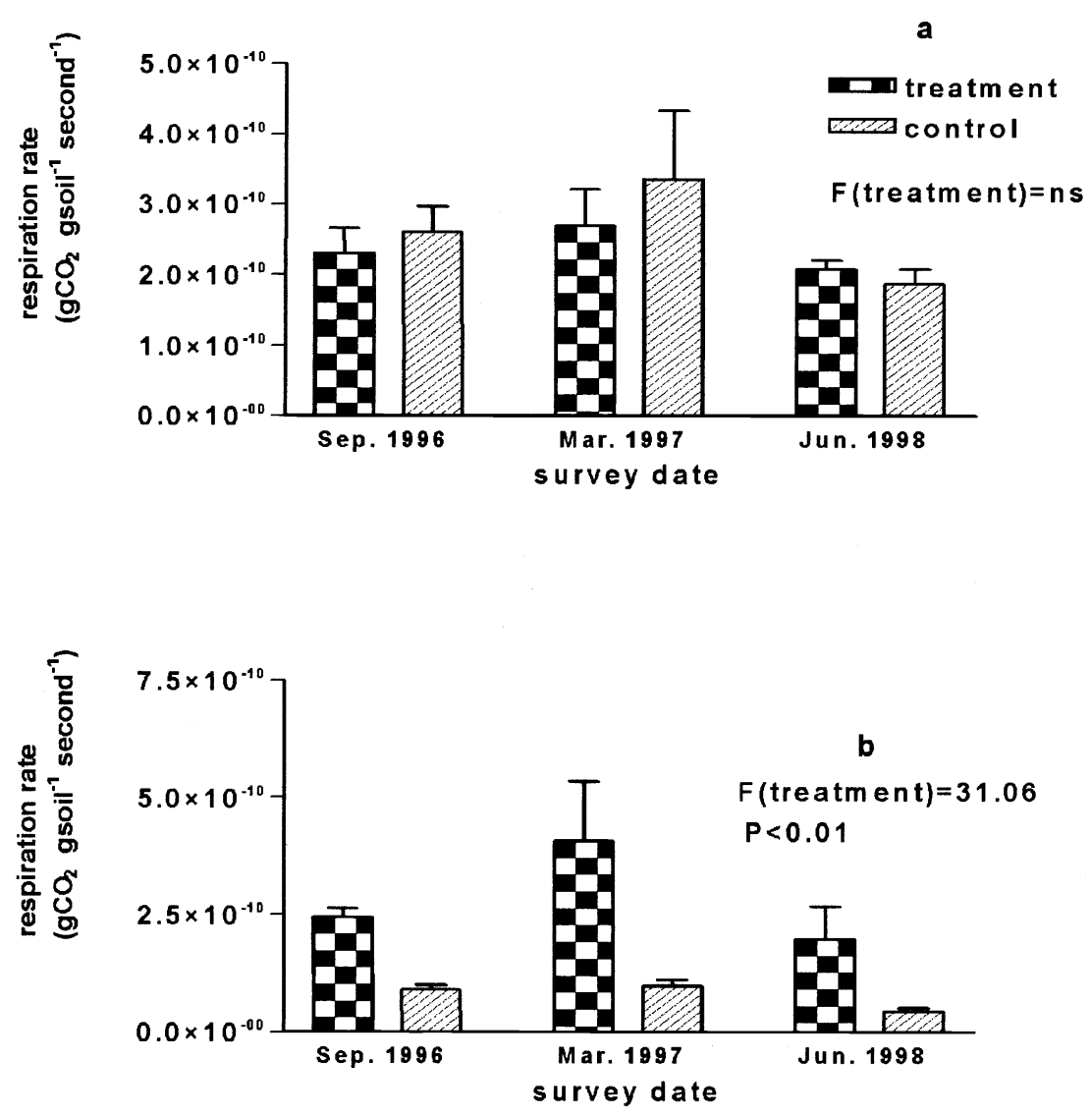

Fig. 1 Soil microbial respiration rates for mound soils (a), and intermound soils (b).

al. 1985, Singer and Warrington 1992). A rainfall simulator was used to determine infiltration and runoff as other methods like infiltrometers in the field and permeameters in the laboratory ignore the negative influence of a seal formation (Morin and Benyamini 1977, Sidiras and Roth 1987). Final infiltration rate $\left(\mathrm{mm} \mathrm{hour}^{-1}\right)$ is measured directly from a graph of infiltration rate vs. cumulative rainfall $(\mathrm{mm})$ when infiltration rate is constant 3 consecutive times. Cumulative infiltration $(\mathrm{mm})$ is calculated as the amount of rain that infiltrates the soil until the final infiltration rate occurs.

\section{Aggregate stability}

Sealing, crusting, water infiltration, runoff and erosion result from aggregate breakdown. The detachment of soil fragments by rain, and the susceptibility of soil to these processes is inferred from measurements of aggregate stability (Morin and Benyamini 1977, Stern et al. 1991, Le Bissonnais 1996). Le Bissonnais (1996) reviewed the 4 main mechanisms (i.e. slaking, breakdown by differential swelling, mechanical breakdown by raindrop impact and physico-chemical disper- sion) of aggregate breakdown, and the existing methods for the assessment of aggregate stability. According to Nearing and Bradford (1985), the main cause of structural degradation at the soil surface is raindrop impact. Therefore, the stability of aggregates was determined from the approach of mechanical breakdown by raindrop impact by using a rainfall simulator. The measure of seal formation employed in this study was the infiltration rate calculated by a Hortonian type equation describing the curve relating infiltration rate $\left(\mathrm{I}_{\mathrm{t}}\right)$ to elapse time $(\mathrm{t})$ :

$$
I_{t}=I_{f}+\left(I_{i}-I_{f}\right) e^{-Y p t}
$$

in which $I_{i}$ is the initial infiltration rate, $I_{f}$ is the final infiltration rate, $\mathrm{Y}$ is a curvefitting parameter related to the stability of the soil aggregates and $p$ is rain intensity (Van der Watt and Valentine 1992). The parameter values were transformed using $1-x$ so that aggregate stability would follow the same trend as infiltration.

\section{Erodibility}

Interrill erosion was estimated based on the area and total runoff from each tray and the calculated sediment concentration.
The interrill erodibility coefficient related to soil properties $\left(\mathrm{K}_{\mathrm{i}}\right.$ in $\mathrm{kg}$ second $\left.\mathrm{d}^{-1} \mathrm{~m}^{-4}\right)$ was calculated from Kinnell (1993);

$$
\mathrm{K}_{\mathrm{i}}=\mathrm{q}_{\mathrm{si}} / \mathrm{I} \cdot \mathrm{Q} \cdot \mathrm{L} \cdot \mathrm{S}_{\mathrm{f}}
$$

where $\mathrm{q}_{\mathrm{si}}$ is the rate of soil discharge from an interrill area $\left(\mathrm{kg} \mathrm{m}\right.$ second $\left.^{-1}\right)$; I the intensity of the rainfall $\left(\mathrm{m} \mathrm{second}^{-1}\right)$; $\mathrm{Q}$ the rate of runoff discharge from an interrill area $\left(\mathrm{m}\right.$ second $\left.{ }^{-1}\right)$; $\mathrm{L}$ the down slope length of the interrill area; and $S_{f}$ a non-dimensional slope adjustment factor that is calculated from $\mathrm{S}_{\mathrm{f}}=1.05-0.85 \exp ^{(-4 \sin (\mathrm{S}))}$, where $S$ is the slope (Kinnell 1993).

\section{Statistical analysis}

The amount of OC was analysed using 2-way analysis of variance with "treatment" and "paddock" as the 2 factors.

Microbial respiration rates were measured on more than 1 occasion (1996, 1997 and 1998). An analysis of variance for repeated measurements was performed to test the null hypothesis that the change over time in the measured parameter would not differ significantly between treatment and control.

For the rainfall simulator results on aggregate stability, final infiltration rate, erodibility and cumulative infiltration paired t-tests (2-tailed) were used to test the null hypothesis that there was no significant difference in the values of the observed variable between treatment and control.

\section{Results}

\section{Soil organic carbon $(\mathrm{OC})$}

Both treatment $(P=0.009)$ and paddock $(\mathrm{P}<0.001)$ had a significant effect on OC amount while the interaction between these 2 factors was not significant $(\mathrm{P}>$ $0.05)$. Non-selective grazing generally resulted in lower OC of the topsoil; more so in paddocks $A$ and $\mathrm{D}$ (Table 1).

\section{Soil microbial respiration rates}

In control areas respiration rates were always significantly higher in mound soils compared to intermound soils. Treatment had no significant impact on microbial activity in mound soils, but resulted in a significant increase in microbial respiration rates in intermound soils (Fig. 1). The time effect and the time $\mathrm{x}$ treatment interaction were not significant.

Aggregate stability, infiltration rate, erodibility, cumulative infiltration

There was a trend for soils from grazed 
Table 2. Characteristics (mean \pm SD) of soils collected from open areas in control and grazing treatment paddocks $(n=4)$ in June 1998. Soils were subsequently subjected to a $44 \mathrm{~mm}_{\text {hour }}{ }^{-1}$ rainfall event using a rainfall simulator. Results of paired t-tests (two-tailed) are shown.

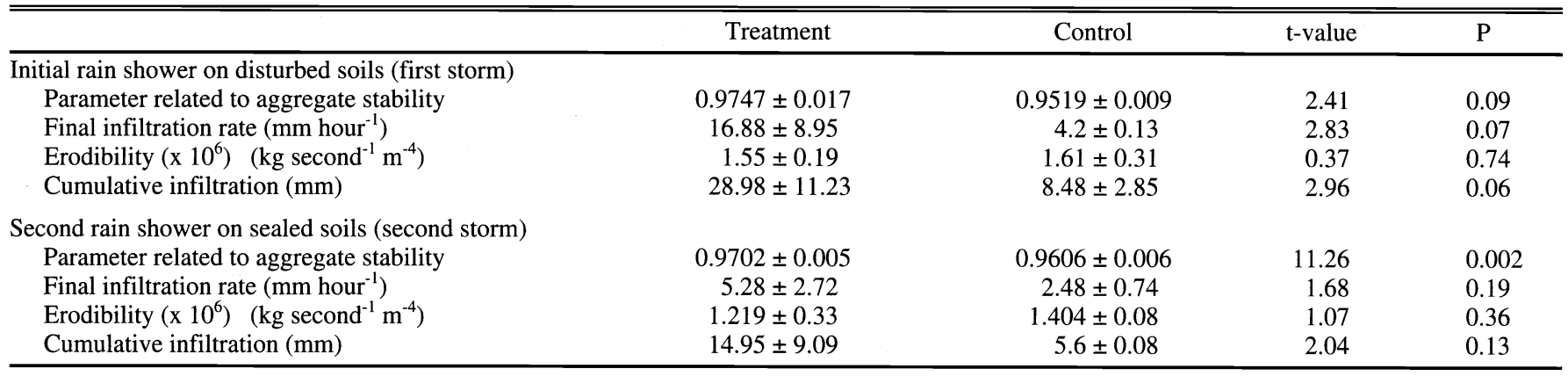

areas to be more stable, and with a better water infiltration capacity compared to control soils when a rain event was simulated on sieved (disturbed) soils (Table 2). There was no significant difference in erodibility. When a rain event was simulated on sealed soils, which is closer to field conditions most of the time, the treatment soils showed a significantly higher aggregate stability compared to the control soils. With this second rain event there were no significant differences in erodibility or infiltration capacity.

\section{Discussion and Conclusions}

Our results do not support the initial hypothesis that non-selective grazing would increase organic carbon (OC). The trend was for soils of grazed areas to have lower OC values compared to ungrazed areas. The visible coarse litter after a nonselective grazing event was not reflected in the OC readings probably because soil samples were passed through a $2 \mathrm{~mm}$ sieve before recording OC content, or there was not sufficient time for the coarse litter to be fragmented. It would appear that the concentrated hoof action concomitant with non-selective grazing did not promote the process of fragmentation. In a study of short-duration grazing (SDG) impacts on range soils in Alberta, Canada, Dormaar et al. (1989) also found that hoof action did not significantly increase incorporation of litter into the soil. The reduced $\mathrm{OC}$ of the topsoil as a result of the nonselective grazing treatment is in accordance with the results of several workers (e.g. Graetz and Tongway 1986, Thurow et al. 1986, Willms et al. 1990, Dormaar et al. 1997) who found that heavy grazing reduced the plant biomass and litter base, and therefore OC of the soils. Since organic matter input is related to standing plant biomass (Garcia-Miragaya and Cáceres 1990), it is possible that with the removal of $>50 \%$ of the forage with non-selective grazing, organic matter input over time was lower in the grazed compared to ungrazed areas.

Another explanation for the trend of lower OC in the grazed areas is related to the significantly higher microbial respiration rates recorded in the intermounds of the grazed areas (Fig. 1). Soil respiration rate $\left(\mathrm{CO}_{2}\right.$ production $)$ depends on the activities of microbial organisms which is controlled by organic matter content, $\mathrm{O}_{2}$ supply, temperature, soil water content, and nutrient supply (Rowell 1994). The pulsed input of organic matter from intensive feeding and trampling and the thorough mixing and aeration of the topsoil by hoof action resulted in a highly active soil biotic community, which rapidly turned over soil OC (McNaughton et al. 1988, Tongway and Ludwig 1996). This grazing impact was not as pronounced in mound soils because of the already loose and friable structure of these soils.

Since soil samples for the rainfall simulator measurements were collected from intermound areas, it is possible to relate the rainfall simulator results to microbial respiration rates of intermound soils. We postulate that the pulsed input of litter and dung together with mixing and aeration of the top layers of non-selective grazing soils led to a rapid increase in soil biotic processes. These soil biotic processes are largely responsible for aggregate creation and stabilisation (Whitford and Herrick 1996). The trend for higher final infiltration rate and cumulative infiltration of the treatment compared to the control soils could be related to the greater aggregate stability of the treatment soils (Greene and Tongway 1989). Furthermore, the increased infiltration in the treatment soils induced a higher water content, which fed back to further promote microbial activities.

The trend for both treatment and control soils to seal, and thereby reduce infiltrability, after an initial rain event (Table 2) is important in confirming field observations that intermound soils become hard and devoid of life when grazed areas are rested for too long (Savory 1983). The longer these unvegetated areas are exposed to raindrop impact and the sun, the more their physical structure can be expected to deteriorate. The challenge is therefore for the manager to avoid returning animals to a paddock too soon, and thus impact negatively on plant productivity, or wait too long and thus reduce rainfall effectiveness.

Holechek et al. (2000) summarized the current knowledge on the merits of shortduration grazing. The evidence they assimilated suggests that short-duration grazing, with its large numbers of animals on small areas for short periods of time, does not benefit soil health but rather results in degradation. Our results point to situations and conditions where high-density grazing might indeed improve water infiltration mainly due to a more active soil biota. This tentative result warrants a reassessment of the positive impacts of high-density grazing systems on soil quality as perceived by amongst others Savory (1983) and McNaughton et al. (1988). There are particularly 3 aspects that we recommend receive further attention: (a) The role of grazing frequency as a factor in determining the impact of large herbivores on soils. The longer rest periods between herding events of non-selective grazing compared to short-duration grazing might be an important difference in terms of soil impacts. The infrequent but heavy grazing of non-selective grazing ensures a pulsed but adequate belowground input of organic matter as a substrate for soil organisms, while soils are loosened and aerated but not compacted; (b) The role of soil type. Our study was conducted on dolerite derived soils with high levels of sesqioxides, high base status and favourable soil structure (Ellis pers comm. 2002). The outcome of herding on more compact soils (e.g. shale) might be 
completely different; (c) The impacts of infrequent, intensive grazing on soil microbial activities and therefore OC dynamics, nutrient cycling and water infiltration. We believe that any grazing system which enhances soil biotic activities will improve overall ecosystem condition and therefore productivity and sustainability.

\section{Literature Cited}

Acocks, J.P.H. 1966. Non-selective grazing as a means of veld reclamation. Proc. Grassl. Soc. South Africa 1:33-39.

Acocks, J.P.H. 1975. Veld types of South Africa, $2^{\text {nd }}$ Ed. Memoirs Botanical Survey South Africa 40:1-128.

Barnard, S.A. 1986. Oumansoutbos in die Winterreënstreek. Boerdery in Suid-Afrika, Weiding Nr. 140.

Ben-Hur, M., I. Shainberg, R. Keren, and M. Gal. 1985. Effect of water quality and drying on soil crust properties. Soil Sci. Soc. Amer. J. 49:191-196.

Beukes, P.C., R.M. Cowling, and S.I. Higgins. 2002. An ecological economic simulation model of a non-selective grazing system in the Nama Karoo, South Africa. Ecol. Econ. 42:221-242.

Biondini, M.E. and L. Manske. 1996. Grazing frequency and ecosystem processes in a northern mixed prairie, USA. Ecol. Appl. 6:239-256.

Biondini, M.E., B.D. Patton, and P.E. Nyren. 1998. Grazing intensity and ecosystem processes in a northern mixed-grass prairie, USA. Ecol. Appl. 8:469-479.

Dormaar, J.F., B.W. Adams, and W.D. Willms. 1997. Impacts of rotational grazing on mixed prairie soils and vegetation. $\mathrm{J}$. Range Manage. 50:647-651.

Dormaar, J.F., S. Smoliak, and W.D. Willms. 1989. Vegetation and soil responses to short-duration grazing on fescue grasslands. J. Range Manage. 42:252-256.

Ellis, F. and J.J.N. Lambrechts. 1986. Soils, p. 18-38. In: R.M. Cowling, P.W. Roux, and A.J.H. Pieterse (eds.) The karoo biome: preliminary synthesis Part I - physical environment. South African Nat. Sci. Program. Rept. No. 124, CSIR, Pretoria, South Africa.

Garcia-Miragaya, J. and A. Cáceres. 1990. Soil chemistry changes in a forest-grassland vegetation gradient within a fire and grazing protected savanna from the Orinoco Llanos, Venezuela. Acta Oecologica 11:775-781.

Graetz, R.D. and D.J. Tongway. 1986. Influence of grazing management on vegetation, soil structure and nutrient distribution and the infiltration of applied rainfall in a semi-arid chenopod shrubland. Aust. J. Ecol. 11:347-360.

Greene, R.S.G. and D.J. Tongway. 1989. The significance of (surface) physical and chemical properties in determining soil surface condition of red earths in rangelands. Aust. J. Soil Res. 27:213-225.
Holechek, J.L., H. Gomes, F. Molinar, D. Galt, and R. Valdez. 2000. Short- duration grazing: the facts in 1999. Rangelands 22 : 18-22.

Kinnell, P.I.A. 1993. Interrill erodibilities based on the rainfall intensity-flow discharge erosivity factor. Aust. J. Soil Res. 31:319-332.

Lavado, R.S., J.O. Sierra, and P.N. Hashimoto. 1996. Impact of grazing on soil nutrients in a Pampean grassland. J. Range Manage. 49:452-457.

Le Bissonnais, Y. 1996. Aggregate stability and assessment of soil crustability and erodibility: I. Theory and methodology. Europ. J. Soil Sci. 47:425-437.

Levy, G.J. 1988. The effects of clay mineralogy and exchangeable cations on some of the hydraulic properties of soils. DSc(Agr.) thesis, Univ. of Pretoria, Pretoria, South Africa.

Low, A.B. and A.G. Rebelo (Eds.) 1996. Vegetation of South Africa, Lesotho and Swaziland. Dept. of Environ. Affairs and Tourism, Pretoria, South Africa.

McCalla, G.R., W.H. Blackburn, and L.B. Merrill. 1984. Effects of livestock grazing on infiltration rates, Edwards Plateau of Texas. J. Range Manage. 37:265-269.

McNaughton, S.J. 1993. Grasses and grazers, science and management. Ecol. Appl. 3:17-20.

McNaughton, S.J., R.W. Ruess, and S.W. Seagle. 1988. Large mammals and process dynamics in African ecosystems. BioScience 38:794-800.

Morin, J. and Y. Benyamini. 1977. Rainfall infiltration into bare soils. Water Resourc. Res. 13:813-817.

Morin, J., S. Goldberg, and I. Seginer. 1967. A rainfall simulator with a rotating disc. Trans. Am. Soc. Agr. Engrs. 10:74-79.

Mworia, J.K., W.N. Mnene, D.K. Musembi, and R.S. Reid. 1997. Resilience of soils and vegetation subjected to different grazing intensities in a semi-arid rangeland of Kenya. African J. Range Forage Sci. 14:26-31.

Nearing, M.A. and J.M. Bradford. 1985. Single waterdrop splash detachment and mechanical properties of soils. Soil Sci. Soc. Am. J. 49:547-552.

Nelson, D.W. and L.E. Sommers. 1982. Methods of soil analysis Part II, p. 570-571. Amer. Soc. Agron. Madison. Wisc.

O'Reagain, F.J. and J.R. Turner. 1992. An evaluation of the empirical basis for grazing management recommendations for rangeland in Southern Africa. J. Grassl. Soc. Southern Africa 9:38-49.

Painter, E.L. and A.J. Belsky. 1993. Application of herbivore optimization theory to rangelands of the Western United States. Ecol. Appl. 3:2-9.

Rowell, D.L. 1994. Soil Science: methods and applications. Longman Group, U.K.

Savory, A. 1983. The Savory Grazing Method or Holistic Resource Management. Rangelands 5:155-159.

Savory, A. 1991. Holistic resource management: a conceptual framework for ecologically sound economic modelling. Ecol. Econ. 3:181-191.
Schulze, R.E. 1997. South African Atlas of Agrohydrology and Climatology. Report TT82/96, Water Research Commission, Pretoria, South Africa.

Sidiras, N. and C.H. Roth. 1987. Infiltration measurements with double-ring infiltrometers and a rainfall simulator under different surface conditions on an Oxisol. Soil Tillage Res. 9:161-168.

Singer, M.J. and D.N. Warrington. 1992. Soil crusting in the Midwestern United States. Adv. Soil Sci. 54:179-204.

Smoliak, S., J.F. Dormaar, and A. Johnston. 1972. Long-term grazing effects on StipaBouteloua prairie soils. J. Range Manage. 25:246-250.

Stern, R., B.E. Eisenberg, and M.C. Laker. 1991. Correlation between micro-aggregate stability and soil surface susceptibility to runoff and erosion. S. Afr. J. Plant Soil 8:136-140.

Thurow, T.L., W.H. Blackburn, and C.A. Taylor Jr. 1986. Hydrologic characteristics of vegetation types as affected by livestock grazing systems, Edwards Plateau, Texas. J. Range Manage. 39:505-509.

Thurow, T.L., W.H. Blackburn, and C.A. Taylor Jr. 1988. Infiltration and interrill erosion responses to selected livestock grazing strategies, Edwards Plateau, Texas. J. Range Manage. 41:296-302.

Tongway, D. and N. Hindley. 1995. Manual for soil condition assessment of tropical grasslands. Division of Wildl. and Ecol., CSIRO, Canberra, Australia.

Tongway, D. and J.A. Ludwig. 1996. Rehabilitation of semiarid landscapes in Australia. I. Restoring productive soil patches. Restoration Ecol. 4:388-397.

Van Der Watt, H. Von H. and C. Valentine. 1992. Soil crusting: The African view. Adv. Soil Sci. 54:301-338.

Whitford, W.G. and J.E. Herrick. 1996. Rangelands in a sustainable biosphere, p. 3337. In: N.E. West (ed.) Maintaining soil processes for plant productivity and community dynamics. Proc. of the $5^{\text {th }}$ Int. Rangeland Congr., Soc. for Range Manage., Denver, Colo.

Willms, W.D., S. Smoliak, and J.F. Dormaar. 1990. Vegetation response to time-controlled grazing on mixed and fescue prairie. J. Range Manage. 43:513-518. 